\title{
Mechanisms for Scaling-Up the Entrepreneurship Potentials of the Agricultural Science Graduates
}

\author{
Thersa Obumneme Okoli \\ Federal College of Education (Technical) \\ P. M. B. 0189, Umumnze \\ Anambra State, Nigeria
}

Doi:10.5901/ajis.2013.v2n5p121

\begin{abstract}
The study was undertaken as a survey on mechanisms for scaling up entrepreneurial potentials of Agricultural Science Education graduates. Four research questions guided the study. A total of 134 respondents made up of 110 students and 24 teachers were used for the study. A structured questionnaire was used for generating data for the study. Data were analysed using frequency and mean. Among the major findings were that the content of the curriculum has enough detail on practical skills; allotted time is insufficient for practical demonstration lessons hence students are not exposed enough to practical lessons; and also indicated that most of the needed facilities and equipment for effective acquisition of practical agricultural skills are not available in the schools. Laboratories and workshops are not properly equipped. Following the findings it was recommended among others that schools should be equipped with modern instructional facilities, enough time should be allocated to practical agriculture; there should be proper funding of agricultural programmes in schools as well as financial mobilization of graduates for entrepreneurial engagements.
\end{abstract}

\section{Introduction}

In a rapidly changing economy, unemployment is among the greatest problems and youth unemployment is nearly three times the factor of the adult unemployment rate (Nwosu, 2004). Nigeria today is faced with economic problems; the economic problems have among other the things given rise to high rate of unemployment, poverty, hunger with its accompanying stress for individuals and families, (Okorie, 2000).

The present situation has occasioned increased awareness in Nigerians of the need for self employment and self reliance. Many school leavers both in secondary and post secondary schools in Nigeria are constantly faced with the problem of unemployment. Nigeria also is faced with numerous political, economic, social and religious problems. These problems in turn gave rise to poverty; unemployment etc and these could in turn be attributed to the kind of education and orientation given to us by the colonial masters. Some attempts have been made to put our educational system into sound footing hence the introduction of 6-3-3-4 system of education, this has the aim of providing the technical knowledge and vocational skills necessary for agriculture, industrial, commercial and economic development for the nation (Federal Republic of Nigeria, National Policy, 2004). This is in line with vocational technical education which is the aspect of education designed to identify occupational skills, harness and develop it, provide knowledge, aptitudes, work habit, abilities necessary for self employment and self reliance as well as adapting to varying environment.

Vocational technical education like other occupational areas according to Step (2000) has intensified emphasis on entrepreneurial competencies for its students with a view to enhancing their capacities for self employment since the field offers many occupational opportunities in such areas as poultry production, crop production, rabbit production, pig production, landscaping, among others. 
Ofodile, (2008) have called for adoption of a functional education that will help an individual to be more self reliant and self employed, reduce unemployment and help the country to attain higher national productivity. Vocational technical education tries to bridge this gap; it tries to provide its graduates with opportunities and skills to be independent. A recipient of vocational technical education has been greatly equipped to face the challenges of the world of work. Unfortunately today, Nigeria is in a very serious unemployment crisis with the educational system churning out year after year, millions of teeming youths, brilliant but unskilled and thus unemployable, even those graduates of vocational technical education are joining the queue for elusive paid employment.

Agricultural education as it exists today does not provide students with enough skills for entrepreneurship. It then becomes necessary to give special attention to this area by providing the students opportunities of improving self employment through entrepreneurship education.

Entrepreneurship education according to Okuala (2003) is important to the entrepreneur, for the valuable skill needed by the entrepreneur can be learnt through trial and error but most of the errors can be eliminated by education. The potential for entrepreneurial success is enhanced when the entrepreneur possess the necessary educational background to function effectively.

Osinem (2008) stated that the concern of Agricultural education is the teaching and learning of skills which will make for proficiency in an agricultural occupation. Through the process of learning the activities and experiences the learner engages in are very vital as they enable student to develop adequate manipulative skills for agricultural productivity which will consequently make for better living in the society. Skills in agricultural production are needed to improve the production of crops, animals and raw materials for man and industries. It is the responsibility of agricultural educators and trainers to determine the right skills need by the student that will enable him to be self sufficient.

\section{Statement of the Problem}

One of the aims of Vocational and Technical education is to give training and impart necessary skills to individual who shall be self-reliant economically. The new curriculum introduced into the Vocational/Technical School system is based on the assumption that once

a student passes through the school system, the student will automatically come out with a saleable skill (Okeke, 2005). However employment trends among agricultural science graduates show that they shy away from entrepreneurship. The question now becomes what are the mechanisms for scaling-up entrepreneurship potentials of the agricultural science graduates?

\section{Purpose of the Study}

This study was designed to find out the mechanisms for scaling-up entrepreneurship potentials of the Agricultural Science graduates specially the study intends to:

1. Find out the extent to which the structure or the course content prepared the student for self employment on graduation.

2. Find out the attitudes of students towards the practical work aspects of the curriculum.

3. Find out if the teaching equipment and facilities are adequate.

4. Find out the mechanisms for scaling-up the entrepreneurship potentials of Agricultural Science graduates.

\section{Research Questions}

The following research questions guided the study: 
1. To what extent does the structure of the course content prepare the students for self employment on graduation?

2. What are the attitudes of students towards practical work aspects of the curriculum?

3. How adequate are the teaching equipment and facilities?

4. What are the mechanisms for scaling - up the entrepreneurship potentials of Agricultural Science graduates?

\section{Methodology}

The population for the study comprised all the final year Agricultural Science Education students numbering 110 and 24 lecturers in the two Colleges of Education in Anambra State namely; Federal College of Education (Technical), Umunze and Nwafor Orizu Collegle of Education, Nsugbe. As a matter of necessity the entire population of 134 respondents was used for the study.

A structured questionnaire weighted on a 4-point rating scale was used for data collection. The instrument was validated by peer review and items that received consensus approval were included. On a Cronbach Alpha Scale, the instrument's reliability was set at 0.71 which was considered high enough for the study.

Data were analysed using frequency and mean. The mean decision point was set as 2.5 which implies that questionnaire items with mean responses of 2.5 and above were accepted as "High extent" while those with mean response less than 2.5 were not accepted at "Low extent"

\section{Results}

Research Question I: To what extent does the structure of the course content prepare the students for self employment on graduation?

Table 1: Mean rating of the responses of the Respondents on the Extent to which the Structure of the Course Content prepare Students for Self Employment.

\begin{tabular}{|c|c|c|c|c|c|c|c|}
\hline$\overline{3 / \mathrm{N}}$ & Items & VHE & $\mathrm{HE}$ & LE & VLE & $\mathrm{X}$ & Remark \\
\hline 1. & $\begin{array}{l}\text { The course content emphasizes on the } \\
\text { theoretical knowledge acquisition }\end{array}$ & 134 & - & - & - & 4.00 & High Extent \\
\hline 2. & $\begin{array}{l}\text { The content covers the practical } \\
\text { skills acquisition }\end{array}$ & 134 & - & - & - & 4.00 & High Extent \\
\hline 3. & $\begin{array}{l}\text { The period allotted for practical work } \\
\text { is enough for skill acquisition }\end{array}$ & - & - & 100 & 34 & 1.75 & Low Extent \\
\hline 4. & The course content is too narrow & - & - & - & 134 & 1.00 & Low Extent \\
\hline 5. & $\begin{array}{l}\text { The course content makes provision } \\
\text { for supervision projects }\end{array}$ & 80 & 54 & - & - & 3.59 & High Extent \\
\hline 6. & $\begin{array}{l}\text { The course content provides for industrial } \\
\text { training before graduation }\end{array}$ & 74 & 60 & - & - & 3.58 & High Extent \\
\hline 7. & $\begin{array}{l}\text { The practical courses offered equip } \\
\text { students with necessary skills for } \\
\text { self employment }\end{array}$ & 42 & 92 & - & - & 3.25 & High Extent \\
\hline 8. & $\begin{array}{l}\text { The course content provides for } \\
\text { design project }\end{array}$ & 134 & - & - & - & 4.00 & High Extent \\
\hline 9. & $\begin{array}{l}\text { The course content makes provision } \\
\text { for agric. field trip }\end{array}$ & 122 & 22 & - & - & 3.54 & High Extent \\
\hline
\end{tabular}


Items 1, 2, 5 and 6 had mean values above the cut- off point of 2.5, showing that the respondents agreed on the items while items 3 and 4 had mean values below the cut-off point was disagreed.

Research Question 2: What are the attitudes of students towards practical work aspects of the curriculum?

Table 2: Mean rating of the responses of the Respondents on the Attitudes of Students towards the Practical work aspects of the Curriculum

\begin{tabular}{|c|c|c|c|c|c|c|c|}
\hline $\mathrm{S} / \mathrm{N}$ & Items & SA & $\mathrm{A}$ & $\mathrm{D}$ & $\mathrm{SD}$ & $\mathrm{X}$ & Remark \\
\hline 1. & $\begin{array}{l}\text { Student show interest towards } \\
\text { the study of the course }\end{array}$ & 62 & 72 & - & - & 3.40 & Agreed \\
\hline 2. & $\begin{array}{l}\text { Students are enthusiastic about their } \\
\text { practical classes }\end{array}$ & 134 & - & - & - & 4.00 & Agreed \\
\hline 3. & $\begin{array}{l}\text { Students participate actively during } \\
\text { practical classes }\end{array}$ & 70 & 64 & - & - & & \\
\hline 4. & $\begin{array}{l}\text { The lecturers require the students to } \\
\text { repeat projects if competency achieved } \\
\text { is below required standard }\end{array}$ & - & 134 & - & - & 3.52 & Agreed \\
\hline 5. & $\begin{array}{l}\text { Students conduct practical themselves } \\
\text { after school period }\end{array}$ & 100 & 20 & 14 & - & 3.64 & Agreed \\
\hline 6. & $\begin{array}{l}\text { Students ask questions and contribute } \\
\text { ideas during the practical classes }\end{array}$ & 134 & - & - & - & 4.00 & Agreed \\
\hline 7. & $\begin{array}{l}\text { The students demonstrate determination } \\
\text { to acquire the desired practical skills }\end{array}$ & 134 & - & - & - & 4.00 & Agreed \\
\hline
\end{tabular}

$\mathrm{N}=134$

All the items in Table 2 above had mean response values of 3.46, 4.00, 3.52, 3.00, 3.64 and 4.00 respectively. These mean values are above the cut-off point and were agreed by the respondents as attitudes of students towards the practical work aspects of the curriculum.

Research Question 3: How adequate are the teaching equipment and facilities? 
Table 3: Mean rating of the Responses of the Respondents on the Adequacy of teaching facilities and equipment for the practical classes

\begin{tabular}{|c|c|c|c|c|c|c|c|}
\hline $\mathrm{S} / \mathrm{N}$ & Items & VAD & $\mathrm{AD}$ & LAD & LAD & $\mathrm{X}$ & Remark \\
\hline 1. & Laboratories for & & & & & & \\
\hline & Agricultural practical & - & - & 80 & 54 & 1.59 & Inadequate \\
\hline 2. & Chemicals and tools in the & & & & & & \\
\hline & Laboratory are enough & - & - & - & 134 & 1.00 & Inadequate \\
\hline 3. & Farm workshops in the school & - & - & 20 & 114 & 1.15 & Inadequate \\
\hline 4. & $\begin{array}{l}\text { Farm land for practical } \\
\text { work }\end{array}$ & 130 & 4 & - & - & 3.97 & Adequate \\
\hline 5. & $\begin{array}{l}\text { The tools in the workshop are in good } \\
\text { working condition }\end{array}$ & - & - & 50 & 84 & 1.37 & Inadequate \\
\hline 6. & Livestock units & - & - & 10 & 124 & 1.09 & Inadequate \\
\hline 7. & $\begin{array}{l}\text { Farm tools and implements } \\
\text { for farm practical }\end{array}$ & - & - & 134 & - & 1.00 & Inadequate \\
\hline 8. & $\begin{array}{l}\text { The laboratory equipment are adequate } \\
\text { for practical }\end{array}$ & - & - & 100 & 34 & 1.75 & Inadequate \\
\hline 9. & Farm machineries are available & - & - & 80 & 54 & 1.59 & Inadequate \\
\hline 10. & Farm inputs are available & - & - & 134 & - & 1.00 & Inadequate \\
\hline
\end{tabular}

$\mathrm{NB}: \mathrm{VAD}=$ Very Adequate, $\mathrm{AD}=$ Adequate, $\mathrm{LA}=$ Less Adequate, $\mathrm{LAD}=$ Least Adequate

Items 1, 2, 5, 6, and 7 had mean values below the cut-off point of 2.50 and was disagreed by the respondents while only item 4 had the mean value above the cut-off point and was agree upon by the respondents.

Research Question 4: What are the mechanisms for scaling-up the entrepreneurship potentials of Agricultural Science graduates? 
Table 4: Mean Responses of Respondents on the mechanisms for scaling-up the entrepreneurship potentials of the Agricultural Science graduates.

$\mathrm{N}=134$

\begin{tabular}{|c|c|c|c|c|c|c|c|c|}
\hline $\mathrm{S} / \mathrm{N}$ & Items & SA & $\mathrm{A}$ & $\mathrm{D}$ & SD & & $\mathrm{X}$ & Remark \\
\hline 1. & $\begin{array}{l}\text { Availability of farm tools and } \\
\text { implements for practical }\end{array}$ & 44 & 90 & & & - & 3.33 & Agreed \\
\hline 2. & $\begin{array}{l}\text { Establishing various units in } \\
\text { Agriculture like Animal, crops etc }\end{array}$ & 134 & - & & & - & 4.00 & Agreed \\
\hline 3. & $\begin{array}{l}\text { The course content to emphasize } \\
\text { more of practical to practical }\end{array}$ & 34 & 100 & - & & - & 3.25 & Agreed \\
\hline 4. & $\begin{array}{l}\text { Enough time to be allotted to } \\
\text { Practical }\end{array}$ & 42 & 92 & - & & & 3.31 & Agreed \\
\hline 5. & $\begin{array}{l}\text { Encouraging students to participate } \\
\text { fully during practical }\end{array}$ & 102 & 32 & - & & - & 3.76 & Agreed \\
\hline 6. & $\begin{array}{l}\text { Facilities and equipment for practical to } \\
\text { be in good working condition }\end{array}$ & 134 & - & & & - & 3.66 & Agreed \\
\hline 7. & Provision of suitable land for farming & 89 & 45 & - & - & & 3.66 & Agreed \\
\hline 8. & $\begin{array}{l}\text { The Federal Government to direct the } \\
\text { NDE to assist financially the graduates } \\
\text { who demonstrate desire for self } \\
\text { employment }\end{array}$ & 134 & - & & & - & 4.00 & Agreed \\
\hline 9 . & $\begin{array}{l}\text { The State Government to establish } \\
\text { matching grants to promote } \\
\text { entrepreneurship among graduates }\end{array}$ & 122 & 12 & & & - & 3.61 & Agreed \\
\hline 10. & $\begin{array}{l}\text { Adequate funding of Agricultural Education } \\
\text { to provide qualitative education experiences }\end{array}$ & 55 & 79 & & & - & 3.41 & Agreed \\
\hline
\end{tabular}

As shown in Table 4 above all the items received mean rating above the cut-off point of 2.5 , showing that the respondents agreed on all the items as the mechanisms for scaling-up the entrepreneurship potentials of the Agricultural Science graduates.

\section{Discussion of Findings}

Research question 1 was designed to find out the extent which structure of the course content prepares the students for self employment on graduation. The responses in table 1 showed that the respondents agreed that the course content did not emphasize unnecessary theoretical knowledge acquisition. They also agreed that the content covers the practical skill acquisition. All the respondents held the view that the periods allotted for practical session are inadequate. Okeke (2005) stated that the demand for a higher degree of skill and efficiency in a chosen vocation needs a constant practice; unfortunately theoretical work seems to have taken over the much needed practical periods.

All the respondents agreed that Industrial training programme was built into the curriculum and that there was a course in the curriculum "supervised projects". Perhaps what the students were asking for was more time for practical work for more meaningful experiences in the farm and workshop. 
Research question 2 tried to find out the attitude of the students towards the practical aspects of the curriculum and results of the study showed that the students were very enthusiastic about practical classes, showed interest, participated actively, and asked questions and contribute ideas. The responses also show that the lecturers did require students to repeat projects when competency achieved fell below minimum standard. This falls in line with what Okuala (2003) stated that for every occupation there is a minimum productive ability which an individual must possess in order to secure or retain employment in that occupation and if vocational education is not carried to that point with that individual, it is neither personally or socially effective.

The third research question addressed the issue of adequacy of teaching facilities and equipment for practices. All the respondents held the view that teaching facilities, equipment and tools are not adequate for the training of the students. The laboratories and workshops are not available; where they are available they are not well equipped. What could the best skilled, highly competent resourceful and creative Agricultural Science teacher do where he has students to teach but nor tools, machines, equipment and other related facilities to impart skills?

Research question 4 was designed to find out the mechanisms for scaling-up the entrepreneurial potentials of Agricultural Science graduates. The results showed that the respondents agreed that availability of teaching facilities, various units or sections of Agricultural Science, allocation of enough time for practical, encouraging the students to participate fully in practical and more emphasis to be laid on practical work can help to enhance the acquisition of skills by the students.

\section{Conclusion}

Unemployment is one of the social problems facing the nation. In order for the graduates to be fully engaged in any meaningful economic activity, relevant skills should be fully acquired. For these sills to be acquired the learner/student should be exposed to a series of theoretical and practical exercises in the workshops and laboratories. The curriculum of Agricultural Science education is sufficiently practical skill-oriented and the student demonstrated interest to acquire the desired sills. So the tools, facilities and materials should be provided in all sections of agriculture. This will provided the much needed experiences in basic management skills for students to handle their own businesses after graduation.

\section{Recommendation}

Based on the findings of the study the following are recommended;

1. Emphasis should be placed more on Agricultural practical and more periods should be allotted to practical work.

2. Colleges should be provided with adequate facilities and equipment for Agricultural education

3. Students should be provided with technical knowledge and vocational skills necessary for agricultural development.

4. The Federal Government may direct the National Directorate for Employment (NDE) to assist financially the graduates who demonstrate desire for self employment in Agriculture. 


\section{References}

Federal Republic of Nigeria (2004). National Policy on Education (Revised), Lagos: Federal Ministry of Education.

Nwosu, I. K. (2004), Youth Unemployment and Poverty Alleviation: Lessons from Developed

Countries. The Nigerian Vocational 1 (3).

Ofodile, S. N. (2003). Entrepreneural Skills Needed for Agricultural Development. A paper Presented at the First Annual Conference Organised by School of Vocational Education. Nwafor Orizu College of Education, Nsugbe. July, 2008.

Okeke, P. O. (2005). Career Development. Enugu: Snap Press Ltd.

Okuala, L. N. (2003). Entrepreneurship Education Ibadan: Macmillan Press.

Okorie, J. U. (2000). Developing Nigerian Workforce Nigeria: Macnky Environs Publishers.

Osinem, E. C. (2008). Managing Agricultural Education and Training: Resources, Principles and Methods. Enugu: Belong International Publishers.

Step 1, (2000). Cognitive Apprenticeship. http/www. Retrieved on (August 4,2000) from Woec. Wisc. 